\title{
AGRICULTURAL INTENSIFICATION: LINKING WITH LIVELIHOOD IMPROVEMENT AND ENVIRONMENTAL DEGRADATION IN MID-HILLS OF NEPAL
}

Nani Raut ${ }^{1}$, Bishal Kumar Sitaula ${ }^{2}$ and Roshan Man Bajracharya ${ }^{3}$

\begin{abstract}
This article reviewed on agricultural intensification from livelihood and environment perspectives in mid-hills of Nepal. Agricultural intensification has provided improved economy, food security, employment opportunities, decision-making, labor division, local institutions and leaderships. But soil degradation has been accelerated along with greenhouse gases emission. Additionally, the potential linkages of agricultural intensification to degradation and pathways for marginalization in the long run are addressed. However, the catalytic role of institution and farmers' perception on intensification are equally important. To ensure socio-economically and environmentally sound production, sustainable agricultural intensification guided by good institutional systems is recommended.
\end{abstract}

Key words: Agricultural intensification, greenhouse gases, institution, livelihood, soil degradation

\section{INTRODUCTION}

Agricultural development has emerged as a major subject of development discourse in livelihood improvement and environment degradation in Asia. Shifting cultivation, the first stage of agricultural development was the most widespread agricultural system in South and Southeast Asia until the mid-20 ${ }^{\text {th }}$ century (Spencer, 1966). It involves basic tools and techniques, low level of inputs and subsistence level of production and consumption (Rasul and Thapa, 2003), which was unable to support growing population and their subsistence needs.

The food security situation was worse in developing countries where the colonial power invested very little on food production systems. After independence, their situations were much worse. The increasing population combined with government control over common property resources was putting pressure on shifting cultivators to reduce the fallow period (Palm et al., 1996 and Gafur et al., 2000). Meantime, shifting cultivators deserve improved lifestyle which was not possible from the low return being provided by their practice of cultivation. Such circumstances forced farmers to seek for more productive agricultural system which otherwise could have brought a hunger and malnutrition situations in Asia. The "crisis" was realized by U.S. President's Science Advisory Committee and came up with a report in 1967. The report concluded that "the scale, severity and duration of the world food problem are so great that a massive, long-range, innovative effort unprecedented in human history will be required to master it" (IFPRI, 2002). In response, Ford Foundation and Rockefeller initiated in establishing the international agricultural research system in order to transfer scientific advances. These advances including high yielding varieties, more use of chemical fertilizers, irrigation and other chemical inputs led to a remarkable yield in Asia in the late 1960s. Such a radical change from hunger situation to dramatic increased yield situation is coined as "Green Revolution".

\footnotetext{
${ }^{1}$ Dept. Int. Env. and Dev. Studies (Noragric), Agri. Uni. of Norway, P.O. Box 5001, N-1432 Ås, Norway Ph.: +47 64965340, fax: +47 64965201, E-mail: nani.raut@umb.no

${ }^{2}$ Dept. Int. Env. and Dev. Studies (Noragric), Agri. Uni. of Norway, P.O. Box 5001, N-1432 Ås, Norway

${ }^{3}$ Dept. of Env. Sci. and Eng., Kath. Uni., P. O. Box 6250, Dhulikhel, Nepal
} 
The objective of the paper is to review and link agricultural intensification from livelihood and environment perspective in the mid-hills of Nepal. It describes improvement in livelihood through the economic, social and institutional indicators and deterioration of environment through soil degradation and greenhouse gases emission. The paper links and discusses agricultural intensification to the degradation and marginalization thesis.

\section{EVOLUTION OF AGRICULTURE DEVELOPMENT IN NEPAL}

Shifting cultivation in Nepal was extensively accomplished by the beginning of the $11^{\text {th }}$ century until $19^{\text {th }}$ century. By the end of $19^{\text {th }}$ century, it was almost substituted by permanent type of agriculture (Rasul and Thapa, 2003). During the Rana regime (18461951), there were no serious attempts made until 1930 for systematic initiation of economic development. In 1937, a development agency was constituted called as 'Udyog Parishad' (Development Board), the major purpose of which was to promote the growth and extension of agricultural, industrial and commercial activities in the country. The Development Board was soon tracked by specialized development agencies, one of which was Agricultural Council (National Planning Commission, 2002). It was established with the objectives of improving farming techniques, irrigation and implementing plans necessary for agricultural development. The Food and Agriculture Organization (FAO) sent its team during this time. After the beginning of the democratic political system in 1951, the first United States Agency for International Development (USAID) subsequently began its assistance programme. Thus, in 1952, a new agricultural plan was developed with a aim of providing information on improved seeds, chemical fertilizer and improved agricultural tools (Dahal, 1997). Until the mid- $20^{\text {th }}$ century, there was a gradual decrease in agricultural inputs and almost collapse of agricultural system. The root causes of the problem were identified as growing population pressure, ecological imbalance, declining productive capacity of soil and increasing pressure on land. Realizing this critical situation, the first conference on agriculture was held on $2^{\text {nd }}$ November 1958 (Dahal, 1997). The focus of the conference was on agricultural development programme, plans and challenges in the development. This was a systematic initiation towards agricultural development in Nepal. Agriculture was the main agenda for the poverty reduction in the Fifth and Sixth Five Year Plan (1974-1985).

\section{AGRICULTURAL INTENSIFICATION AND IMPROVED LIVELIHOOD}

In Nepal, the average land holdings decreased by 0.17 ha; from 0.96 ha in $1991 / 1992$ to 0.79 ha in 2001/2002 (CBS, 2002). Such trend has seriously threatened the livelihood and food security of those who depend on agriculture (Thapa and Niroula, 2008). The situation is even worse in mid-hills where landholdings of farmers are small and the opportunities for them to have other sources of income from non-agricultural activities are also limited. Therefore, vast majority of Nepalese hill farmers have chosen land intensification as an alternative approach for livelihood.

\section{ECONOMIC INDICATOR}

Several studies done in mid-hills show that economy of the farmers involved in agricultural intensification, has been reported to be improved (Katwal and Sah, 1992; Brown and Kennedy, 2005 and Dahal et al, 2007). For example, in Khani Khola area of Dhading district, farmers have intensified the land by vegetable cultivation. This has contributed to tripling household incomes over the last 15 years (Katwal and Sah, 1992). The yield has increased in both cereal-based and vegetable-based cropping patterns by $41 \%$ and $61 \%$ respectively. The net income from the vegetable production is found to be significantly high as compared to cereal crop production (Tiwari et al., 2008). Similarly, in Phewatal watershed, an increase in cash crop production has resulted in a tripling of household incomes (Dahal et al., 2007 and Poudel, 2002). There are several factors that bring relatively higher income from intensified agriculture. These factors are intensive care of plots by farmers during leisure time, use of high yielding varieties, high inputs of chemical fertilizers compared with 
traditional cultivation system, high labor inputs and high market prices of the crop they have chosen.

\section{SOCIAL INDICATOR}

Food security is important social determinant of the livelihood. The shift from subsistence cereal farming to an intensive vegetable-based farming system has significantly improved the food security mainly among the poor and disadvantaged groups in mid-hills of Nepal. The vegetables growers have increased their income from farm by selling vegetables in nearby markets and thus, from the income, they can buy food and other household items from the same market. It is reported that only half of the farmers relying on cereal-based cropping pattern could meet food requirement for only half the year. But after intensive vegetable farming, over half of the famers have increased their household income to avoid food shortage (Tiwari et al., 2008). Thus, agricultural intensification enhanced the quantity of food produced, improvements in food security (Katwal and Sah, 1992; Carswell, 1997; Dahal et al., 2007 and Tiwari et al., 2008;) and farmers are also able to consume more nutritious food in terms of more green vegetables in their diet (Tiwari et al., 2008).

Agricultural intensification has increased employment opportunities for local people in mid- hills. It opens new opportunity of employment in the markets of agricultural products, fertilizers and pesticides. Farmers with large landholdings hire local farmers who have small landholdings, for cultivation and transport of farm production up to the market (Tiwari et al., 2008). Furthermore, labor wages has also been increased which benefited the poor and disadvantaged groups.

The decision-making processes at household level have been changed after the intensification process has been introduced (Rasul and Thapa, 2003). The autonomous decision making process led by household head has been changed to consensus-based decision making process together with all family members. The decision making particularly in selection of crop varieties, adoption of new technologies and marketing of farm produces has changed (Tiwari et al., 2008).

There is the clear division of labor and responsibilities among the family members in Nepal. Male members mostly involve in plough, digging, threshing and marketing. Female members involve in planting, farm yard manure application and harvesting of crops. The shift from cereal-based production to vegetable production system has changed the social values at local level and somehow got rid of the existing division of labor between male and female and among different caste systems (Tiwari et al., 2008). Both male and female are engaged in land preparation, planting, fertilizer buying and application and harvesting the crops. Both of them are involved in selling their farm produce in the market and buying household consumption materials and vegetable inputs. Such marketing activities help them in providing access to price information, opportunity to expose themselves to other communities and interact with them, increase bargaining power of their farm products and make them able to compete in the market. Also the caste-based division of labor has been changed to some extent. Before, the so called higher caste people (Brahmin and Chhetri) did not plough the land and used to hire the lower caste people. But because of adoption of agricultural intensification, lower caste people started cultivating vegetables in their own farm land by observing higher caste people getting benefit from it (Tiwari et al., 2008). As lower caste people get busy on their own farm, there is the situation of labor shortage for higher caste people, thus giving them relatively lower returns than before. In this way, the shift from traditional agricultural system to more intensive agriculture system has changed labor division to some extent.

INSTITUTIONAL INDICATOR

Institutional indicators like local institutions and leadership are the indicators for livelihood improvement. Community-based local institutions (the self-initiated local level 
institutions) in the region includes Conservation and Development Groups (CDGs), Community Forest User Groups (FUGs) and Women Groups (WGs). CDGs focus on integrated farmland and resource management in which all member households participate in a regular meeting regarding experiences about the farming. Such social capitals encourage

local farmers, women and disadvantaged groups to participate in decision making process, for leadership development, social mobilization and encourage them for saving and credit programs (Preety, 1995 and Tiwari et al., 2008). Some of the Users' Groups have leaders from the minority groups and women which show that the discrimination based on caste and gender has been decreasing with the adoption of agricultural intensification.

\section{OTHER FACE OF AGRICULTURAL INTENSIFICATION: SOIL DEGRADATION AND GREENHOUSE GAS EMISSION}

As an outcome of globalization and modernization, farmers in mid-hills started adopting new farming technology and modern inputs which were almost unknown to most of the illiterate farmers before. They adopted by seeing others doing it. Further, inadequate training and lack of effective regulations regarding subsidy policies made the modern inputs cheaper leading to an excessive use of it. This has led to negative environmental impacts. The country's average crops per annum have increased from 1.6 in 1986 to 2.7 for irrigated agriculture and to 2.5 for rain-fed agriculture in mid 1990s (Westarp et al., 2004) because of which an excessive and inappropriate use of chemical fertilizers and pesticides with an aim of increasing production has almost overlooked essential environment factor.

\section{SOIL DEGRADATION}

Soil degradation implies decline in soil quality due to anthropogenic activities. It has mainly three principal processes: physical process includes crusting, compaction and erosion; chemical process includes nutrient depletion, leaching, acidification and salinization; and biological process includes depletion of soil organic matter and reduction in soil biodiversity. Agricultural intensification raises concerns about soil erosion, nutrient depletion, water quality and soil organic matter depletion (Gardner and Gerrard 2003; Shrestha et al., 2004 and Westarp et al., 2004). These concerns are particularly relevant in the mid-hill regions of Nepal where the region has been intensively cultivated and the majority of the population is dependent upon land to accomplish their basic needs. Soil erosion is a serious problem in the mid-hills (Sitaula et al., 2000).

The issue of accelerated erosion was developed from a number of studies and impressionistic writings, which claimed that Nepal would slide away into Ganges by the year 2000 and that the Nepalese hill farmer was to blame for this situation (Biot et al., 1995: 96).

Soil loss through surface erosion from the agricultural land in hills varies from less than 2 tons ha ${ }^{-1}$ year $^{-1}$ to highest soil loss of 105 tons ha $^{-1}$ year $^{-1}$ (Acharya et al., 2007). Soil losses are found to be higher in Bari land on sloping terraces (32 tons/ha/year) than in Khet $^{2}$ land (less than 1 ton/ha/year) which is directly related to slope gradient and it is cheaper to make sloping terraces than making level terraces (Shrestha et al., 2004 ). Thus, the frequent breaking and loosening of soil through regular hoeing and plough had forced soil to erosion. Soil degradation through nutrient depletion is also a serious issue (Lal, 2000) Many studies have shown that soils in mid-hills have very low nutrients especially nitrogen and phosphorous (Shah and Schreier, 1991; and Brown 1997; and Westarp et al., 2004). In particular, the double and triple annual cropping rotations are more nutrient demanding. Thus in order to fulfill nutrient requirements, increased number of crops per annum has

\footnotetext{
${ }^{1}$ Rain-fed uplands with maize based cropping system

${ }^{2}$ Irrigated lowlands with rice based cropping system
} 
increased the inputs of chemical fertilizers in their farm. As a consequence of increased fertilizer use during intensification process, soils in mid-hills are becoming more acidic (Westarp et al., 2004).

The intensification also leads to the deterioration of nearby water bodies like rivers. During the monsoon time, heavy rainfall takes away tons of soil with nutrients from hills to the water bodies. It has been found that water bodies near to the intensification area have higher concentration of nitrogen, phosphorous and potassium. This is due to higher amount of chemical fertilizer use for intensive production of crops and the nutrients have been washed down (Dahal et al., 2007).

\section{GREENHOUSE GAS EMISSION}

Methane $\left(\mathrm{CH}_{4}\right)$ and nitrous oxide $\left(\mathrm{N}_{2} \mathrm{O}\right)$ are the most significant greenhouse gases that are emitted from the agriculture practices. Agricultural intensification contributes directly to emissions through variety of processes. But, the paper will focus on emissions from crop intensification looking into the levels of chemical fertilizer inputs, tillage frequency, number of crops per year and types of cultivation. Most of the $\mathrm{N}_{2} \mathrm{O}$ from soils is produced mainly by two biological processes, namely nitrification and denitrification. $\mathrm{N}_{2} \mathrm{O}$ evolved from soils either by oxidation of ammonium to nitrate by nitrifying microorganisms under aerobic condition or by reduction of nitrate by denitrifying microorganisms under anaerobic conditions (Bremner, 1997). The process is accelerated when soils are treated with ammonium or ammonium yielding chemical fertilizers. Similarly, net $\mathrm{CH}_{4}$ production has been found to be increasing in the high-input cropping system due to increased soil respiration resulting in anaerobic conditions. Methane oxidation was lower in fertilized than in unfertilized soil as there was an excess of $\mathrm{NH}_{4}^{+}$concentration in the fertilized soil. Frequent tillage in soil, exposes soil surface and releases carbon dioxide that is presented as sequestered in soil particles.

Many studies have been done on linking agricultural intensification and greenhouse gas emission in different countries (Ojima et al., 1993; Pathak, 1999; Sitaula et al., 2000; and Werner et al., 2004) which shows that the intensification process led to the emission of climate gases. Only few studies have been done in Nepal. It has been found that land-use changes in mid-hills from forest or grassland to flooded rice fields were and are still significant sources for $\mathrm{CH} 4$ release into the atmosphere (Awasthi, 2004). Referring to the previous established research, it can be said that intensified cropping system in the midhills will probably have tremendous greenhouse gas emissions.

\section{CHANGING CLIMATE AND NEPALESE AGRICULTURE}

There are some evidences that the climate has been changing in Nepal. The temperature has been increased by $1.8^{\circ} \mathrm{C}$ during last 32 years and the average temperature increase was recorded as $0.06^{\circ} \mathrm{C}$ per year. The rainfall pattern is also experienced as inconsistent with higher intensities of rain and less number of rainy days (Malla, 2008). The emission of methane from rice field supplied with $50 \%$ nitrogen fertilizer was $49 \mathrm{~kg}$ per hectare which is quite high without irrigation facilities (Malla, 2006). The plains (Terai) of Nepal faced a problem of rain deficit during 2005 and 2006 due to early monsoon which reduced the crop production by $12.5 \%$ on national basis. Around $10 \%$ of the country's arable land was left fallow due to rain deficit where as there was flood in mid western Terai, that decreased production by $30 \%$ in the same year (Malla, 2008). Early maturity of the crops due to increasing temperature helps to increase the number of crops per year. But increasing number of crops lead to increase in agricultural activities like tilling and agro-inputs. This has potential implication on soil degradation and emission of greenhouse gases in the fragile landscape of mid-hill region. 


\section{ESTABLISHING THE POTENTIAL LINKAGES OF AGRICULTURAL INTENSIFICATION TO THE DEGRADATION AND MARGINALIZATION THESIS}

By now, the positive and negative effects of agricultural intensification have been identified. It is also discussed on how farmers perceive intensification despite their knowing and unknowingness about environmental degradation that it causes. To be unbiased, livelihood of people comes first. Unless a farmer could feed his family, how could he think

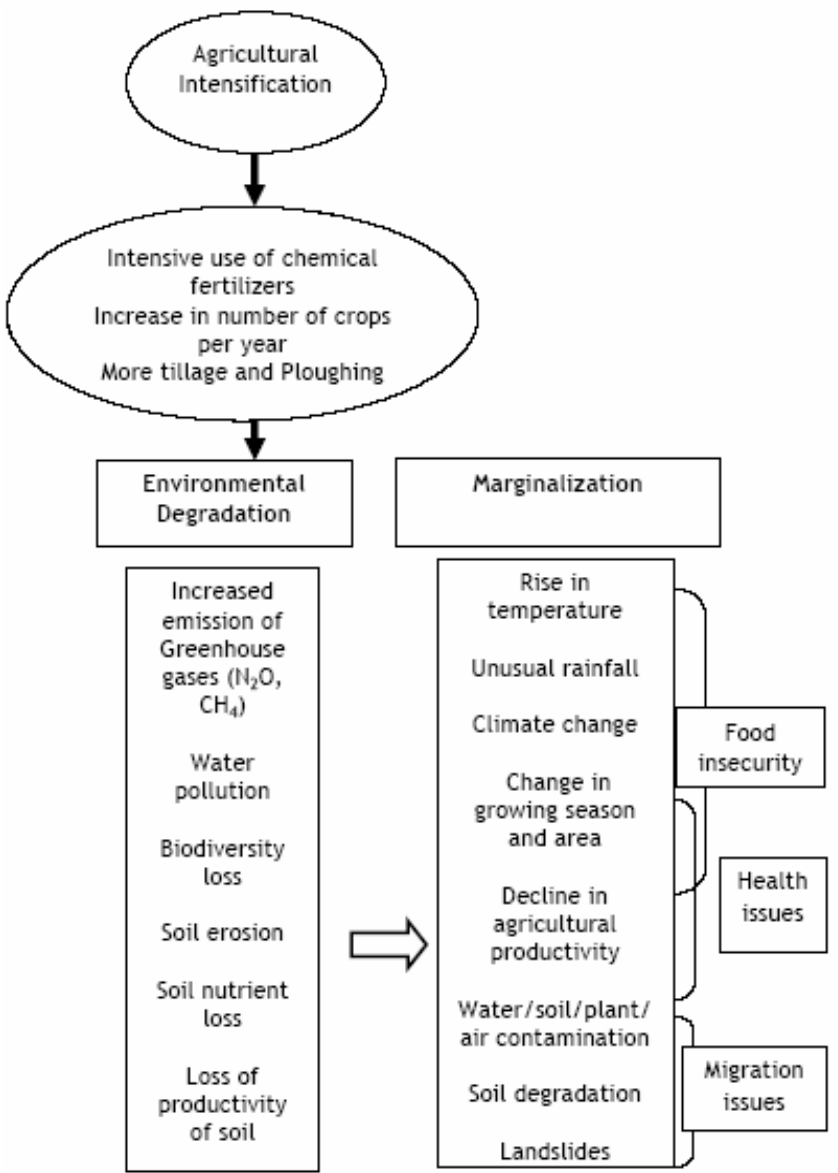
of other factors? I strongly agree on it. But the potential risk in a long run which is very contextual is also a serious issue. The cost of potential damage caused by environmental degradation might exceed the cost of livelihood improvement. The potential effects will then have profound influence on who gets to eat and who does not, who is forced to migrate and who is not, and who controls the labor of others and who does not. With this background I would like to put forward the main thesis: "Otherwise environmentally innocuous local production systems undergo transition to overexploitation of natural resources on which they depend as a response to state development intervention and/or increasing integration in regional and global markets" (Robbins, 2004:131).

Fig. 1: Establishing the linkages between agricultural intensification potentially leading to marginalization

The process of marginalization due to intensification might be local. There are many factors like topography, socioeconomic condition, institution that play a great role in differing the process of marginalization due to intensification. There are different potential pathways for marginalization that are traced within the framework of the concept of this paper. Fig. 1 shows the linkages which are discussed below.

\section{FOOD INSECURITY}

It is primarily through changes in temperature, rainfall pattern, growing season that will affect agriculture. A big concern for developing countries due to changing climate is the possibility of decrease in the agricultural productivity, which may create a scenario of food 
insecurity. The changing climate may not be favourable for some of the varieties of crops. Specific impacts, possibly, will be complex; however, most researches concluded that fauna and flora are very vulnerable to small changes in climate (Gisladottir and Stocking, 2005). For example, in middle and higher latitudes, global warming tend to extend the length of potential growing season, earlier planting, maturation and harvesting and the possibility of two or more crops within the same season. But then more crops require more tilling of fragile land in mid-hills which eventually leads to soil degradation. Also the addition of chemical fertilizers leads to the emission of greenhouse gases which again affect the unusual weather pattern. In lower and warmer latitude regions, the increased temperature accelerates the rate of plant respiration that provides less than optimal condition for net growth, thus crops respond negatively with decline in growth and yield (Rosenzweig and Hillel, 1995). Also, the warmer temperature is favourable for the invasion of different pests that are agents of livestock disease. This in turn cuts the food supply of meat and dairy products.

\section{HEALTH ISSUES}

Agricultural intensification process produces food in larger quantities with different level of diversity. Such situation increases food availability at lower prices for the farmers and leading to access to food. Thus, on a positive side, agricultural intensification potentially reduces the food borne illness whereas on the other side, the productivity might decline due to unusual temperature and rainfall pattern. The situation might be much worse in mid-hills where the soil is very fragile. Soil, air, water bodies and even plants are contaminated with overuse of chemical fertilizers and pesticides through different pathways. The direct and indirect exposure to fertilizers and pesticides will have direct consequences to human health. The economic loss due to ill health of farmers is of concern. There have been many episodes of water/vector borne diseases due to irrigation canals, ditches, etc. constructed for agricultural purposes (Mutero et al., 2006).

\section{MIGRATION ISSUES}

There have been evidences of increasing soil erosion, nutrient depletion and soil acidification in the mid-hills as we have already discussed above. The soils are deficient in nitrogen, phosphorous and sulphur and other micronutrients (Blaikie and Sadeque, 2000). Thus soil fertility of the mid-hill region is not rich enough to sustain the need of increased agricultural production for the growing population. Marginal households become less able to secure the labor or capital inputs to manage changing soil conditions, thus people probably think of leaving the land and move to some other places where the land is more fertile. It will be easier for farmers to accept migration situation created by unsustainable practices more easily, in the situation where adults from mid-hills are frequently moving to other places due to different socio-political reasons (Dutt, 1981).

\section{INSTITUTIONS AS A CATALYST}

Institution refers to different policies, institutions and organizations that are involved in the process of intensification.

National Agricultural Policy- More than 80 percent of the country population is dependent on agriculture. So, the national agricultural Policy of Nepal put emphasis on agricultural production through the use of agro inputs, road networks, marketing infrastructure and rural electrification (NPC, 1995 and Dahal et al., 2007). Earlier, government provided fertilizer subsidies to encourage investments in agriculture from 1973/74 until 1996/97. This policy was brought in to serve two purposes: first, encouraging farmers to use fertilizers by providing at relatively low price, and second, discouraging outflow of fertilizers from Nepal to India. This directed the government to bear huge financial burden as subsidy allocation. Thus, the government decided to deregulate the subsidy policy 
(1997/98-2007/08). Since one of the objectives of National Fertilizer Policy (NFP, 2002) is to enhance fertilizer consumption through policy and infrastructure management and deregulation policy failed to bring desirable impact on improving supply situation and quality control on fertilizer, the government has decided again to providing fertilizers at subsidized rate. One of the features of the later decision is that the fertilizers will be distributed according to the technically required amount for three crops a year. This clearly shows that National Agricultural Policy and Fertilizer Policy have emphasized on intensification process (policy paper by MoAC, 2009).

Government institutions- There are different field level government institutions like Agricultural and Livestock Extension offices. But these offices do not seem very effective. Some of the extension models tried so far includes: (i) the traditional approach in which JTA $^{1}$ is expected to provide assistance to anybody for any problem; (ii) the training and visit approach applied mostly in Terai; (iii) the tuki (a Nepali term used for kerosene lamp) approach in which JTA acted both as a source of information and a commission agent for purchased inputs he/she supplied; (iv) farming system approach, further concentrating on service delivery in selected sites of having higher potentials; $(v)$ the group approach in which farmers' groups are constituted according to the main commodity they grow like rice group, vegetable group etc (Blaikie and Sadeque, 2000). The extension offices are supposed to educate local farmers about new varieties of crops and vegetables, to monitor and control the quality of improved seed, fertilizers and pesticide use. Integrated pest management (IPM $\left.{ }^{4}\right)$ technology has already been launched in view of controlling the pest. However, implementation of such mechanisms might not be strong.

Market mechanisms- Agricultural marketing comprises buying, selling, storage, processing, standardization, certification and distribution of farm products. The process of transfer from farmers to consumers has to pass through a channel including changes in their forms and prices (Pokhrel and Thapa, 2007). The farm produces are taken to the nearby markets through middleman who decides prices of farm produce. The prices are based on the previous day's wholesale market price and also include transport cost, tax, quality of products and profit margin. Most of the local farmers are unaware of market prices. Thus, the middleman gets benefit than the local farmers while selling the farm produce. Agricultural policymakers in many developing countries perceive them as parasites who take away a large share of the benefit from crop selling (Ellis, 1996; Pokhrel and Thapa, 2007 and Tiwari et al., 2008). The traders and middlemen are cheating farmers taking advantage of their lack of knowledge of market prices and poor bargaining power arising from illiteracy and low social status which further weakens when combined with seasonal shortfalls of cash, and lack of storage facilities (Thapa et al., 1995; Banskota and Sharma, 1999; and Shrestha and Shrestha, 2000). In addition, middleman provides agricultural inputs and other household goods on loan to the local farmers. Such situations have obliged them to sell their products to the same middleman so that they repay their credit. As the farmers are able to get chemical fertilizers on loan, they will not have control on using the fertilizers. In addition, they always want to get cash out of their farm produces without taking risk of its storage. Thus it can be said that the worse market mechanism is pushing farmers to practice for intensified farming.

\section{FARMERS’ PERCEPTION ON AGRICULTURAL INTENSIFICATION}

Agricultural intensification has serious implication on environmental degradation. But how farmers perceive intensification as a problem for environment is influenced by many factors. Farmers' personal characteristics, feelings and ambition significantly persuade on the adoption of new technologies and methods of production (Poudel and Thapa, 2004). The

\footnotetext{
1 Junior Technical Assistant

${ }^{4}$ Integrated Pest Management
} 
productivity depends on what technologies are applied and which cropping method is practiced. Thus, the degree of intensification depends on the peoples' choice on techniques of doing agriculture.

Those farmers who are illiterate and have less exposure to society and institutions may not easily consider management practices compared with literate farmers (Mehta and Killert, 1998 and Rauniyar, 1998). The consideration of environmental degradation by farmers also depends on the farmers' household size, income source and also on social background like rich, poor and the caste they belong to. If the major income source is based on agriculture, then they may not prefer to consider environmental degradation due to intensification. People whose main income source is not agriculture are less concerned about land conservation issues compared to those whose livelihood primarily based on agriculture (Poudel and Thapa, 2004).

\section{TOWARDS SUSTAINABLE AGRICULTURAL INTENSIFICATION}

The concern of feeding a fertile population from infertile soil in fragile and marginal agricultural land in mid-hills is really a dilemma. The situation of food security and socioeconomic condition could become worse unless the agricultural productivity and rural economies get better. The intensification process can be adopted but with appropriate technologies and in ecologically friendly way. Thus a path towards sustainable intensification would be an option. Then the question comes how to achieve it? As soil is the primary thing for enhanced agricultural production, approaches towards integrated nutrient and pest management have already been launched. The misconception on farmers about high doses of chemical fertilizer inputs increase the productivity can be somehow made clear through improvements in IPM and farmers' field schools. Policies can be made to enforce environmental taxes on nitrogen fertilizers, promote better timing of fertilizer and manure application. Sustainable agricultural intensification could be achieved through adoption of high yielding varieties, terracing, legume intercropping, contour hedgerows, cover crops, minimum tillage, selection of appropriate crops, organic and inorganic fertilizer use etc. On top of that good institutional system plays a great role to guide the sustainable agricultural practices. The creation of local institutions that increase the market strength of small farmers and the presence of state policies that support powerless to compete, will lead sustainable agriculture economically feasible.

\section{CONCLUSION}

Agriculture being the main occupation of Nepal, the developmental plans has focused on increasing the agricultural production in order to meet food demand of the growing population. Farmers in the mid-hills are widely practicing the intensification through intensive use of chemical fertilizers, pesticides, introduction of agro equipments and increasing number of crops per year.

Agricultural intensification has a positive implication on livelihood security in terms of better economic condition, social conditions like food security, employment opportunity and improved division of labor; and improved institution. But on the other side, intensification has potential negative implications on soil degradation through soil erosion, nutrient depletion and soil acidification; and climate change through emission of greenhouse gases. The emissions of $\mathrm{CH}_{4}$ and $\mathrm{N}_{2} \mathrm{O}$ from agricultural soil are increased especially due to tillage, fertilizer inputs and irrigation, key elements of agricultural intensification. In order to have a better understanding of the implications due to agricultural intensification, more specific knowledge of the linkages between agricultural intensification, environmental degradation and its potential pathways to marginalization is established. 
Indeed, the role of institutions like government institutions and market mechanisms play a vital role in implementing policies that should enable and encourage for sustainable development based on local resources and local knowledge. In order to follow a middle path to secure both livelihood and environment, an approach to sustainable agricultural intensification would be a think piece.

\section{REFERENCE}

Acharya, G. P., McDonald, M. A., Tripathi, B. P., Gardner, R. M. and K.J. Mawdesley, 2007. Nutrient losses from rain-fed bench terraced cultivation systems in high rainfall areas of the mid-hills of Nepal. Land Degrad. Develop, 18: 486-499.

Ananda, J. and G. Herath, G., 2003. Soil erosion in developing countries: a socio-economic appraisal. Journal of Environmental Management, 68(4): 343-353.

Angood, C., Chancellor, F., Hasnip, N., Morrison, J. and L. Smith, 2002. Contribution of irrigation to sustaining rural livelihoods: Nepal case study. Report OD/TN 113. Wallingford: HR Wallingford Ltd.

Awasthi, K. D., 2004. Land-use change effects on soil degradation, carbon and nutrient stocks and greenhouse gas emission in mountain watersheds. PhD dissertation submitted to Department of Plant and Environmental Science, Agricultural University of Norway.

Banskota, K. and B. Sharma, 1999. Traded Resource Flows from Highland to Lowland. International Center for Integrated Mountain Development, Kathmandu.

Biot, Y., Blaikie, P.M., Jackson, C. and R. P. Jones, 1995. Rethinking research on land degradation in developing countries. World Bank Discussion Papers, pp. 96.

Blaikie, P. M. and S. Z. Sadeque, 2000. Policy in high places: Environment and development in the Himalayan Region. International Centre for Integrated Mountain Development, Kathmandu, Nepal.

Boserup, E., 1965. The conditions of agricultural growth: The economics of agrarian change under population pressure. London: Earthscan Publications Ltd.

Boserup, E., 1993. The Condition of Agricultural Growth: the Economics of Agrarian Change under Population Pressure, London: Earthscan.

Bremner, J. M., 1997. Sources of nitrous oxide in soils. Nutrient cycling in Agroecosystems, 49:7-16.

Brown, S., 1997. Soil fertility, nutrient dynamics and socio-economics interactions in the middle mountains of Nepal. PhD thesis, Interdisciplinary studies in resource management science, university of British Columbia, Vancouver, BC.

Brown, S. and B. Shrestha, 2000. Market-driven land-use dynamics in the middle mountains of Nepal. Journal of Environmental Management, 59: 217-225.

Brown, S. and G. Kennedy, 2005. A case study of cash cropping in Nepal: Poverty alleviation or inequity? Agriculture and Human Values, 22: 105-116.

Carswell, G., 1997. Agricultural intensification and rural sustainable livelihoods: A think piece. IDS Working Paper 64.

CBS, 2002. Statistical pocket book of Nepal 2000. Central Bureau of Statistics, Kathmandu.

CBS, 2003. Statistical year book Nepal 2000. Central Bureau of Statistics, Kathmandu.

Dahal, N., 1997. A Review of Nepal's first conference on agriculture. Water Nepal, 5(2): 149-164.

Dahal, B. D., Sitaula, B. K., and R. M. Bajracharya, 2007. Sustainable agricultural intensification for livelihood and food security in Nepal. Asian Journal of Water, Environment and Pollution, 5(2):1-12.

Dahal, B. D., Sitaula, B. K., Sharma, S. and R. M. Bajracharya, 2007. Effects of agricultural intensification on the quality of rivers in rural watersheds of Nepal. Journal of Food, Agriculture and Environment, 5(1): 341-347.

Dutt, S., 1981. Migration and development. Economic and Political Weekly, 16(24):1053-1055.

Ellis, F., 1996. Agricultural Policies in Developing Countries. Cambridge University Press, Cambridge.

Gafur, A., Borggaard, O. K., Jensen, J. R. and L. Peterson, 2000. Changes in soil nutrient content under shifting cultivation in the Chittagong Hill Tracts of Bangladesh. Danish Journal of Geography, 100:37-46.

Gardner, R. A. M. and A. J. Gerrard, 2003. Runoff and soil erosion on cultivated rainfed terraces in the Middle Hills of Nepal. Applied Geography, 12: 23-45. 
Gisladottir, G. and M. Stocking, 2005. Land degradation control and its global environmental benefits. Land Degradation and Development, 16, 99-112.

ICIMOD, 1992. Strategies for sustainable mountain agriculture in the Middle Hills of Nepal. International Centre for Integrated Mountain Development, Kathmandu, Nepal.

IFPRI, 2002. Green Revolution, curse or blessing? International Food Policy Research Institute. Washington, D.C.

Katwal, B., and L. Sah, 1992. Transformation of mountain agriculture: case study, Mountain Farming Systems (discussion paper no. 26) (pp. 79), Kathmandu: International Centre for Integrated Mountain Development.

Lal, R., 2000. Controlling greenhouse gases and feeding the globe through soil management. The Ohio State University, Columbus, Ohio.

Malla, G., 2006. Effect of different fertilizers in reducing Methane gas emission from rice fields. Summer crop workshop proceedings.

Malla, G., 2008. Climate change and its impact on Nepalese agriculture. The Journal of Agriculture and Environment, 9: 62-71.

Mehta, J. N., and S. R. Kellert, 1998. Local attitudes towards community-based conservation policy and programs in Nepal: A case study in the Makalu-barun conservation area. Environmental Conservation 25 (4), 320-333.

Ministry of Agricultural and Cooperatives, 2009. A policy paper on Lagat sahabhagita ko aadharma rasayanik malma sahayog upalabdha garaune sambandhi prastab (in Nepali). Kathmandu, Nepal.

Mutero, C.M., McCartney, M. and E. Boelee, 2006. Understanding the links between agriculture and health. Vision for food, agriculture and the environment. International Food Policy Research Institute. USA.

NPC, 1995. The Eighth Plan (1992-1997). Kathmandu: National Planning Comission.

NPC, 2002. Nepal's Tenth Plan. National Planning Commission. Available at : http://www.npc.gov.np/ tenthplan/the_tenth_plan.htm, retrieved on: 25 November, 2008.

NFP, 2002. National Fertilizer Policy. Government of Nepal.

Ojima, D. S., Valentine, D. W., Mosier, A. R., Parton, W. J. and D. S. Schimel, 1993. Effect of land use change on methane oxidation in temperate forest and grassland soils. Chemosphere, 26: 675:685.

Poudel, G. S., 2002. Coping with land scarcity: Farmers' changing land-use and management practices in two mountain watersheds on Nepal. Norwegian Journal of Geography, 56: 21-31.

Poudel, G. S., and G. B. Thapa, 2004. Impact of social, institutional and ecological factors on land management practices in mountain watersheds of Nepal. Applied Geography, 24: 35-55.

Palm, C.A., Swift, M.J. and P. L. Woomer, 1996. Soil biological dynamics in slash-and-burn agriculture, Ecosystems and Environment, 58: 61-74.

Pathak, H., 1999. Emissions of nitrous oxide from soil. Current Science. 77(3): 359-369.

Pokhrel, D. M. and G. B. Thapa, 2007. Are marketing intermediaries exploiting mountain farmers in Nepal? A study based on market price, marketing margin and income distribution analyses. Agricultural Systems, 94: 151-164.

Preety, J.N., 1995. Regenerating Agriculture: Policies and Practice for Sustainability and Self Reliance (pp. 131-163). London: Eartscan Publication.

Preety, J.N., 1998. Supportive policies and practices for scaling up sustainable agriculture. In N.G. Roling and M.A.E. Wagemakers (eds.) Facilitation Sustainable Agriculture (pp. 23-40). Cambridge: Cambridge University Press.

Rasul, G. and G. B. Thapa, 2003. Shifting cultivation in the mountains of South and Southeast Asia: Regional patterns and factors influencing the change. Land Degrad. Develop. 14: 495-508.

Rauniyar, G.P., 1998. Adoption of management and technological practices by fishpond operators in Nepal. Aquaculture Economics and Management, 2 (3): 89-99.

Robbins, P., 2004. Political Ecology: A Critical introduction. Degradation and Marginalization (pp.131) Blackwell Publishing, USA.

Rosenzweig, C. and D. Hillel, 1995. Potential impacts of climate change on agriculture and food supply. Consequences, 1(2). 
Seddon, D., 1988. Nepal: A state of Poverty. Vikas Publishing House: New Delhi.

Shah, P. B. and H. Schreier, 1991. Soil fertility and erosion issues in the middle mountains of Nepal. Workshop Proceedings. Kathmandu, Nepal. 1991. International Development Research Center, Ottawa, ON.

Sitaula, B. K., Newpane, R. P., Paudel, G. S., Sankhyan, P. L. and B. R. Singh, 2000. Land degradation in the Himalayan region: an interdisciplinary approach for analyzing system behaviour. In: J. Låg (ed.), Geomedical Problems in Developing Countries. The Norwegian Academy of Science and Letters, Oslo, pp.193-208.

Shrestha, B. and R. L. Shrestha, 2000. Marketing of mandarin orange in the western hills of Nepal: constraints and potentials. Lumle Agriculture Research Station, Nepal.

Shrestha, D. P., Zinck, J. A. and Van Ranst, E., 2004. Modelling land degradation in the Nepalese Himalaya. CATENA, 57 (2): 135-156.

Smith, J., Barau, A. D., Goldman, A. and J. H. Mareck, 1994. The role of technology in agricultural intensification: the evolution of maize production in Northern Guinea Savanna of Nigeria. Economic Development and Cultural Change,42 (3): 537-554.

Spencer, J. E., 1966. Shifting cultivation in Southeastern Asia. University of California Press: Berkeley, CA.

Thapa, G. B. and G. S. Niroula, 2008. Alternative options of land consolidation in the mountains of Nepal: An analysis based on stakeholders' opinions. Land Use Policy, 25: 338-350.

Thapa, G.B., Koirala, G.P., Gill, G.J. and M. B. Thapa, 1995. Constraints on Agricultural Marketing in Nepal. Winrock International, Kathmandu.

Tiwari, K.R., Nyborg, I.L.P., Sitaula, B.K. and G. S. Paudel, 2008. Analysis of the sustainability of upland farming systems in the Middle Mountains region of Nepal. International Journal of Agricultural Sustainability, 6(4): 289-306.

Westarp, S.V., Schreier, H., Brown, S. and P. B. Shah, 2004. Agricultural intensification and the impacts on soil fertility in the Middle Mountains of Nepal. Canadian journal of Soil Science, 323-332. 